\title{
The Little Gardener: Science Learning for Children
}

\author{
Mirawati \\ Universitas Muhammadiyah, Tasikmalaya, Indonesia \\ Corresponding e-mail: mirapaud@gmail.com
}

\begin{abstract}
This article discuss about study related with the application of little gardener program which is conducted in Preschool UPI as an effort to introduce science and concept of nature and also to give learning experience naturally for children. This study is aimed to see the description of gardening activity implementation for children, the advantage of gardening for children's development aspect and also how the children familiar with natural environment through gardening activity. The result of finding showed that gardening activity capable to give learning experience naturally to children in recognizing various science concepts. Gardening also give contribution to physical-motor development, language, cognitive, socio-emotional and also moral-religious of children, so it can be concluded that gardening activity capable to give positive result toward various children's development integrally..
\end{abstract}

Keywords: $\quad$ Nature, Children, Science, Gardening

\section{INTRODUCTION}

Science learning included natural concept for children is an effort to help them finding certain concept and process in life, in other word science learning for children essentially made to become media which is used to stimulate development aspect and to maximize children's potency. This is in accord with Havu-Nuutinen (Gross, 2012, p. 1-2) who said that science education is a process of conceptual change in which children reorganize their existing knowledge in order to understand concept and process more completely.

Furthermore, science learning for early children can give positive experience to help them in developing understanding about a science concept, developing thinking ability, inculcating positive attitude, and giving strong foundation to science concept development in the next education level (Trundle, 2009).

Science learning for children is not only activity of introduction and teaching related with certain science concepts for children, but an effort used to stimulate development aspect and to maximize children potency (Gross, 2012). In other word, in process of science learning, it is not science concept which is emphasized to be understood by children, but more directed to how that science learning capable to become tool to stimulate various aspects of children's development from earlier.

Worms, Shadow and Whirlpools (Halverson, 2007) stated the advantages of science learning for children among others are capable to cultivate children's self-confidence in their environment, give important experience directly to children, develop basic concept of natural science, enhance the ability in observing, get the opportunity to use material which can be used in science learning, so children started to be accustomed with that from earlier, get a help in solving the problem, get the opportunity to stimulate their curiosity and get the opportunity to explore, develop sensor, physical, intellectual, emotional, spiritual and social abilities and develop linguistic ability through vocabulary addition when children do activity of questioning and answering.

The explanation above imply the importance of science learning experience for children in various school level, included in preschool level and elementary school. Unfortunately, science learning in these two levels sometimes not optimal in its implementation, usually limited to activity of direct 
practice, demonstration and frequently fixated to textbook or students worksheet. Concept taught to children tend to become rigid and less suited with children development stage, so tend to force children to understand that science. Whereas, basically good learning for child is learning which capable to give direct experience and capable to stimulate children development integrally, not only to develop one aspect (Suyadi \& Ulfah, 2013; Santrock, 2007).

The basic aim of science learning for children is to develop development aspect and children potency. Besides, science learning also aimed to develop individual in order to recognize the scope of science itself and capable to use fundamental aspects in solving the problem they face. Thus, the focus of science learning development program is intended to cultivate understanding, interest and appreciation of children of the world where they live namely the universe (Trundle, 2009).

The National Science Education Standards (Bosse et al, 2009; Kellough, 1996) explained the scope of science learning for early children, among others are as follow:

a. Science as Inquiry. Science learning as process which give opportunity to children to predict, investigate, estimate, group and develop children ability in finding concept and theory.

b. Physical Science. Science learning as process to give direct experience for children to interact with science material and encourage them to take initiative and have courage in exploring that science material.

c. Life Science. Science learning as process to help children to capable to formulate questions related with the characteristic of object/living things and non-living things through observation activity.

d. Earth and Space Science. Science learning comprise the study material of earth and universe.

e. Science and Technology. Science learning comprise the relatedness of science and technology. In this case, children can distinguish natural objects and human-made objects.

f. Science in personal and social perspective. Science learning as the effort to bring science concept in personal and social perspective In addition, Leeper (Nugraha, 2008) also suggested that science learning development in children should enable children to have ability in solving the problem they face through the use of science method, so children are helped and become skilful in solving various problems they face, have scientific attitudes and acquire the scientific knowledge and information, included the concept of natural science.

One activity which capable to give science learning experience integrally to children is through gardening activity, as had been implemented in Preschool UPI. This activity included in program which is called little gardener and become one of routine activities in each year. Little gardener program is a program intended to familiarize children to natural environment through gardening activity, both in short time and long run. There are many advantages which are obtained through that program implementation. particularly for achievement of various aspect of children development, so that program can be made to become alternative of meaningful science learning for children.

Based on explanation above, the author intended to explained further science learning in children through the application of little gardener, with hope that this paper capable to give more comprehensive insight for readers concerned with alternative of creative and meaningful science learning for early children.

\section{METHOD}

The method used by author to conduct this study is qualitative method, in which the author is intended to describe and interpret the application of little gardener program in Preschool UPI. Data collection technique used comprise three techniques namely observation, interview and documentary. Data which are obtained in the field then analysed through qualitative approach with thematic analysis technique (Thomas \& Harden, 2007; Alwasilah, 2010). Based on this, thematic analysis in this study are about the application of little gardener program and the relatedness between little gardener program and science concept.

\section{FINDINGS}

\subsection{Form and Implementation of Little Gardener Program}

Little gardener program in Preschool UPI is one of routine programs done in each academic year, particularly in plant theme. The aim of this little gardener program is familiarize children to nature 
through gardening activity. Some stages in application of little gardener program which are implemented are as follow:

\section{a. The Planning of Gardening Activity}

In this stage, teacher invite children to plan gardening activity, discuss what are needed in gardening activity, what plants which are possibly planted and prepare the steps of gardening activity which will be done. In this stage teacher can also introduce gardening to children with storytelling.

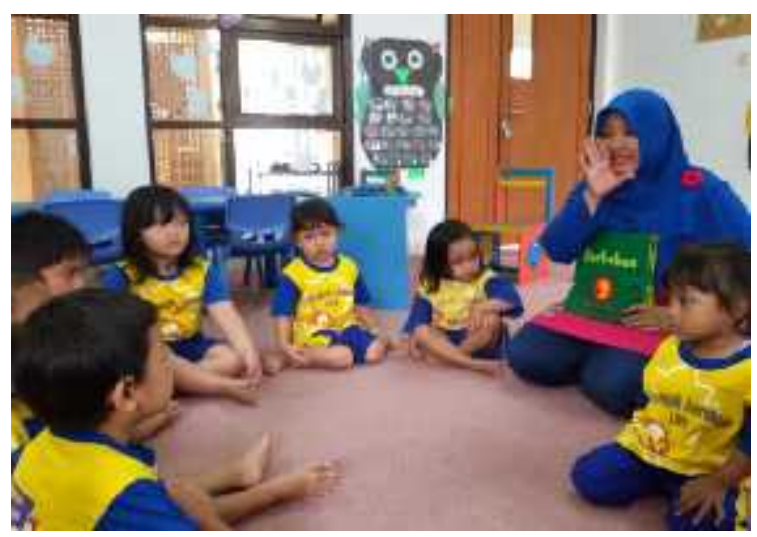

Figure 1. Storyteling about gardening activity for young children

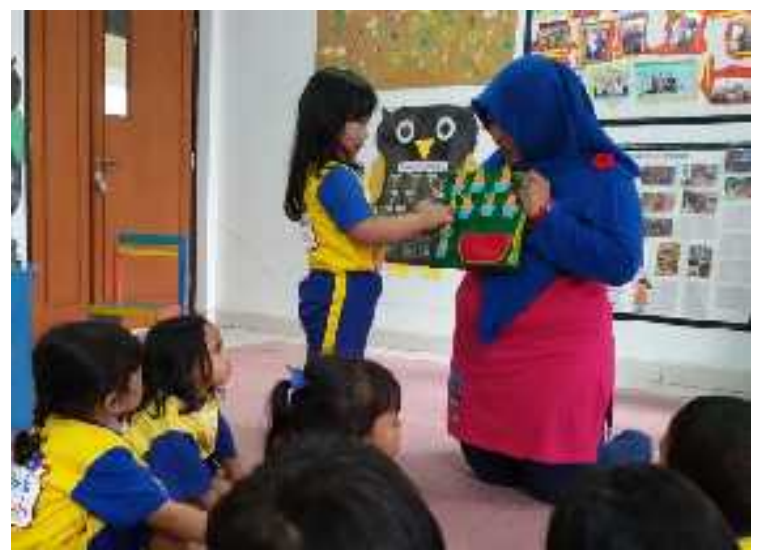

Figure 2. Storyteling about gardening activity for young children

In Figure $1 \& 2$, it can be seen that the teacher are doing storytelling for children related to gardening. Teacher encourage children to get to know the activities of gardening and start planning gardening activities. In the storytelling activities, teacher use interesting books for children and can stimulate the curiosity of children related to gardening.

\section{b. The Implementation of Gardening Activity}

In this stage, teacher and children do gardening activity in accord with plan which had been arranged before. Teacher remind children about the steps to grow the plants well. The implementation of this gardening activity needs a relatively long time and gardening process not stopped after children planted whatever plants, but also continued in plant maintenance process, for example by watering the plants regularly, give fertilizer, etc.

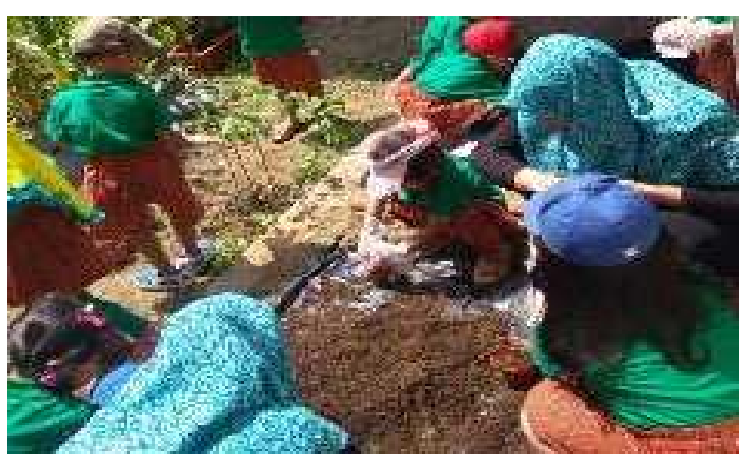

Figure 3. Gardening activity in in Preschool UPI

Figure 3 illustrates the gardening activities done by children in preschool UPI. On gardening activities this time the children are planting scallion. In this activity the child to enter the soil in the pot, then plant the scallion which has been prepared by the teacher on each pot they have

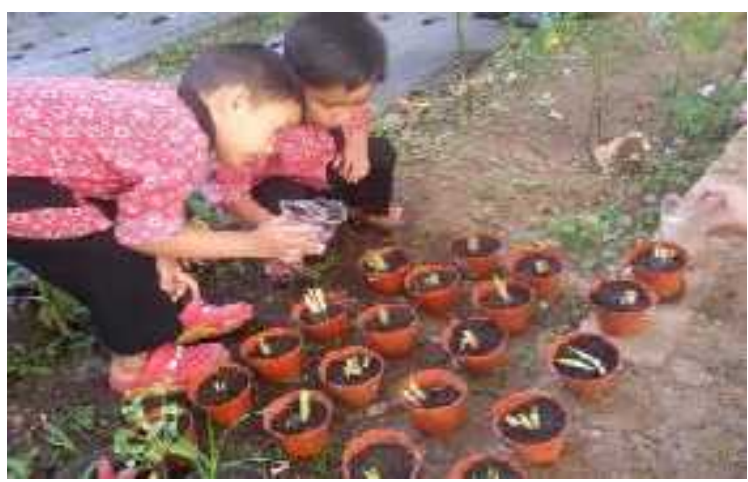

Figure 4. Children watering the Plants

In Figure 4, the child was seen watering the plants. This plant watering activities performed by children every morning, while watching the growth of scallion that they have planted earlier.

\section{c. Evaluation of Gardening Activity}

This stage is done by reviewing the implementation of gardening activity which had been done by children. Evaluation also done to 
monitor the growth of plants in garden. In this stage, teacher can also invite children to cook the plants.

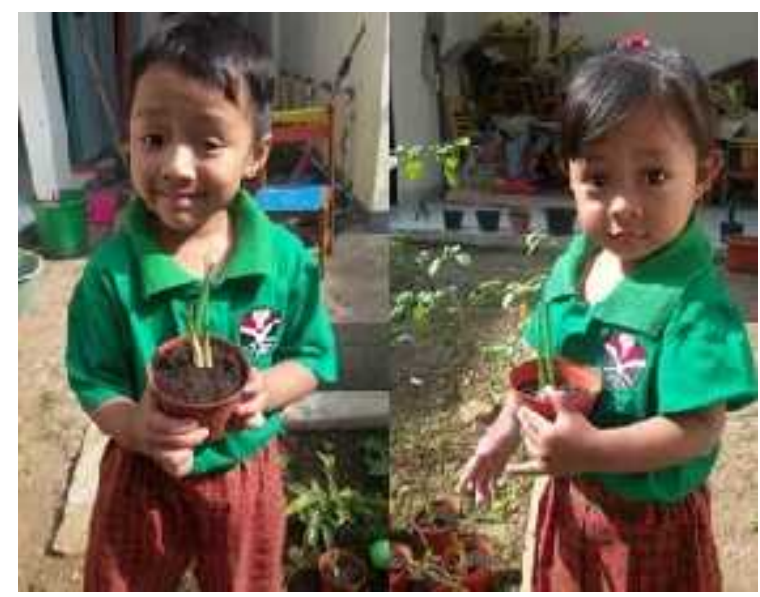

Figure 5. Proud to be "Little Gardener"

\subsection{The Advantage of Little Gardener Program Implementation}

Some of advantages observed when implementing little gardener program in Preschool UPI among others are as follow (Remaklus, 2014; Langellotto \& Gupta, 2012; McLennan, 2010, Nimmo \& Hallet, 2008):

a. Grow children's love toward nature by familiarizing children to plants surrounding them.

b. Enable children to move actively, because gardening process automatically involve all children's senses, for example when helping to put the seeds, pour soil into pot, water the plants, etc.

c. Children can learning by doing. The experience obtained through working is learning outcome which not easily forgotten, therefore in teaching learning process it is better to direct children to do an activity or "Learning by Doing."

d. Children learn to understand plant growth process. Through gardening activity, children are able to see the proof, that if the plants which 'drink' or 'eat' sufficiently then will grow healthy, and vice versa.

e. Children are able to know the process of planting, maintaining and cooking the plants to become delicious food. Gardening activity also capable to grow children interest toward certain vegetables which children not like before such as scallion.

f. Add children insight about the name of objects used in gardening activity, name of plants and also another terms which children can obtain when doing gardening activity.

g. Gardening for young children is fun activity which can invoke pleasant and enjoyable atmosphere, so it will encourage children to take a part in learning process, therefore in each learning, the enjoyable atmosphere through fun activity is need to be created

\section{CONCLUSIONS}

Little gardener program is made to become alternative of science learning for early children because there are many advantages which can be obtained from gardening activity for children. Besides introducing science learning, gardening also give contribution to physical-motor, language, cognitive, social-emotional and also moral-religious development of children, so it can concluded that gardening activity capable to give positive result toward various aspects of children development integrally.

\section{ACKNOWLEDGEMENTS}

The author would like to thank the teachers, children and parents in Preschool UPI, as well as all those who have helped in the writing of this article.

\section{REFERENCES}

Bosse, S., Jacobs. G, \& Anderson, T.L. (2009). Science in the air. Young Children, 64 (6), p.10-15.

Gross. (2012). Science concepts young children learn through water play. Dimensions of Early Childhood, 40 (2), p. 3-12.

Halverson. K. (2007). Science in Early Childhood. Retrieved from www.uwlax.edu.

Kellough, R. D. (1996). Integrating Mathematic and Science For Kindergarten and Primary School. Collumbus, Ohio: Merril Prentice Hall.

Langellotto, G.A., \& Gupta, A. (2012). Gardening increases vegetable consumption in schoolaged children: A meta-analytical synthesis. Hortechnologi, 22 (4), p.430-445. 
McLennan, D. M. P. (2010). "Ready, Set, Grow!' Nurturing young children through gardening. Early Childhood Educ J, 37 (1), p. 329-333.

Nimmo, J., \& Hallet, B. (2008). Childhood in The Garden, a place to encounter natural and social diversity. Beyond the Journal, Young Children on the Web, January 2008, p. 1-8.

Nugraha, A. (2008). Pengembangan Pembelajaran Sains Pada Anak Usia Dini. Bandung: JILSI Foundation.

Remaklus, U. (2014). Putting the Garden to Sleep: Understanding the Meaning of Nature. Voices of Practitioners 9 (1), p.1-20.

Santrock, J. W. (2007). Perkembangan anak, Child development, eleventh edition, Jilid 1. Jakarta: Erlangga.

Suyadi \& Ulfah. (2013). Konsep dasar PAUD. Bandung: PT. Remaja Rosdakarya.

Thomas, J and Harden, A. (2007). Methods for the thematic synthesis of qualitative research in systematic reviews. London: Social Science Research Unit.

Alwasilah, C. A. (2011). Pokoknya action research. Bandung: PT. Kiblat Buku Utama.

Trundle, K. C. (2009). Teaching Science during the Eraly Childhood Years. National Geographic, Hampton Brown 